\title{
A ciência do diálogo
}

\section{The science of dialogue}

\author{
Carlos Fioravanti \\ Jornalista, editor de ciência da revista \\ Pesquisa Fapesp \\ fiora@trieste.fapesp.br
}

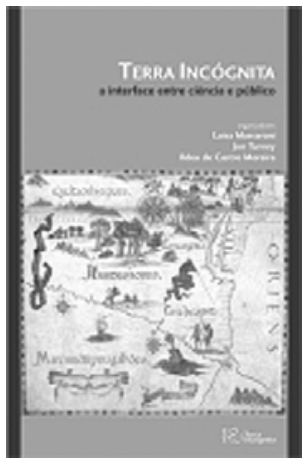

Luisa Massarani; John Turney; Ildeu de Castro Moreira (org.) Terra Incógnita - a interface entre ciência e público

Rio de Janeiro, Casa da Ciência, UFRJ/Museu da Vida/Fiocruz/Vieira \& Lent, 2005, 256p.
$\mathrm{T}$ empos atrás, quando saiu o filme $O$ dia depois de amanhã , os cientistas ingleses concluíram que era o momento de se exporem e de se comunicarem de forma mais clara e direta com o grande público. Falaram das imprecisões conceituais do filme, mas, acima de tudo, aproveitaram para alertar sobre as possibilidades reais de mudanças climáticas. Por aqui, não consta que esse filme tenha ganhado destaque além do previsível, restrito aos suplementos culturais dos jornais, embora nem todas as oportunidades desse tipo sejam perdidas. Há alguns anos, quando foram procurados pela equipe de produção da novela $O$ Clone, geneticistas de São Paulo rapidamente deixaram os preconceitos de lado e concluíram que se tratava de uma oportunidade preciosa para passar mensagens corretas a milhões de brasileiros.

O livro Terra Incógnita - a interface entre ciência e público, organizado por Luisa Massarani, John Turney e Ildeu de Castro Moreira, mostra exatamente como criar ou aproveitar momentos como esses. O nome do livro retoma a expressão usada pelo astrônomo egípcio Cláudio Ptolomeu para designar os territórios desconhecidos na época em que a chamada civilização se resumia à Europa e à Ásia. A analogia, aplicada à tarefa de divulgar a ciência ao grande público, indica que nem todos os espaços foram conquistados, mas o mapeamento, como esse livro mostra, está bem avançado, embora não faltem problemas.

O espaço dedicado às novidades sobre ciência tem crescido nos jornais, rádios e televisões do mundo todo, mas, não só por aqui, talvez pudesse ir mais longe - ou mais rápido - se contasse com mais cuidados, com métodos e objetivos claros, com uma formação cultural mais esmerada dos jornalistas e com mais flexibilidade dos pesquisadores para falar com públicos que não são os mesmos dos congressos científicos a que costumam ir. É o que, em essência, demonstram os jornalistas ou acadêmicos da Europa, dos Estados Unidos ou do Canadá que assinam treze artigos considerados fundamentais para entender e melhorar a divulgação científica - alguns já haviam sido publicados em outros livros e saem agora em português, enquanto outros foram escritos especialmente para esse livro.

As experiências recentes, como o noticiário sobre Aids, analisado pelo pesquisador britânico Harry Collins e pelo norte-americano Trevor Pinch, mostram claramente quão altas são as montanhas que se impõem em meio à paisagem. Ora surgem equívocos na forma de tratar o público, ora faltam objetivos comuns entre os autores de um trabalho científico e os repórteres. O mapa apresentado por esse livro mostra que também se pode, facilmente, escorregar na linguagem: imaginemos 
que o cientista, acostumado a falar apenas com seus colegas, tão especializados em uma área da ciência quanto ele, por alguma razão deixe de explicar um conceito importante para um jornalista (mas como é que ele não sabe o que é um íntron?!); e ao escrever o redator, por pressa ou falta de hábito de buscar as lacunas do texto, deixe de explicar esse conceito ao leitor - e a matéria sai truncada e obscura, descontentando a todos. Para evitar desastres e decepções, por que não reconhecer o medo de pisar em terras desconhecidas, apostar em um pouco mais de conversa e valer-se de menos pompa de todos os lados?

Para o coração de uma descoberta científica não se perder, é preciso conhecer muito bem a audiência, ressalta a professora de jornalismo Carol Rogers, em um artigo muito interessante, publicado originalmente em inglês em 1999. O problema é que "as audiências permanecem um enigma", reconhece essa pesquisadora da Universidade de Maryland, Estados Unidos. "Sabemos bastante sobre o interesse do público pela ciência e sabemos bastante sobre como a ciência é apresentada nos meios de comunicação de massa. Mas sabemos bem menos sobre como as diversas audiências dão sentido às informações a respeito de questões científicas complexas, nas quais a incerteza é um componente importante." Ela comenta um estudo feito em 1998 pelo National Science Board, dos Estados Unidos, mostrando que só dez por cento dos norte-americanos sabem o que é uma molécula e só vinte por cento conseguem definir DNA. Mesmo assim, o estudo também evidenciou o interesse do público pelas notícias sobre ciência, vistas como uma forma de obter informações essenciais para a vida moderna.

Carol Rogers examina os resultados de um estudo feito com seis grupos de discussão formados por adultos com 22 a 87 anos, que apenas tinham ouvido falar - sem nenhum conhecimento aprofundado sobre Aids e aquecimento global. Primeiro, comentaram o noticiário sobre esses dois assuntos em jornais, rádio e televisão. Depois, opinaram. A queixa geral foi de falta de informações básicas, que tornariam as matérias mais compreensíveis. "Mais especificamente", relata Carol Rogers, "os participantes acharam que as matérias pressupunham níveis de conhecimento por parte da audiência - fossem eles leitores de jornais, espectadores de televisão ou ouvintes de rádio - de que eles não dispunham". Um dos participantes reclamou: "Não tenho a menor idéia do que seja um inibidor de protease. E gostaria que houvesse um parágrafo ou algumas frases a respeito do que isso é. Porque isso faria com que o artigo fosse muito mais ... informativo para mim".

Outra reclamação, que ainda hoje pode ajudar a rever a forma pela qual cientistas e jornalistas estão se comunicando: a falta de contexto. Em seu artigo, a professora de jornalismo assinala: "De forma recorrente, os participantes do grupo de discussão expressaram frustração com relação à falta de contexto nas matérias. Tanto no caso da Aids quanto no caso do aquecimento global, eles queriam saber onde essa informação se encaixa no quadro maior do que veio antes e do que veio depois. Sem essa contextualização, eles tinham dificuldade para dar sentido à informação e para decidir sobre sua importância no esquema maior das coisas".

Vem daí a recomendação: “Os jornalistas precisam fazer um esforço 
maior para conhecer o publico para o qual fazem suas reportagens. Eles não podem simplesmente pressupor que a audiência compartilha de sua formação, de seu conhecimento ou da atenção que atribuem à notícia ... Ao ouvir o que as audiências têm a dizer sobre o tipo de reportagem que é necessário para que se tenha um bom entendimento, os jornalistas terão maior chance de apresentar um produto que atenda melhor também às necessidades do seu público". Como é lembrado no livro, há também o risco da acomodação: uma vez encontrada uma fórmula que funcione, não se sai mais dela, caindo em estilos batidos e automáticos, sem vida, nos quais a forma predomina sobre o conteúdo.

A preocupação com a alfabetização científica percorre todo o livro. É certo que as novidades têm maior impacto quando os leitores já conhecem o assunto de que se está falando, mas, como se reconhece, é muito difícil saber o que os leitores deveriam saber para não se sentirem desconfortáveis diante de uma descoberta científica. Em seu artigo, publicado inicialmente em 1993, John Durant, que atualmente dirige o Museu do Instituto de Tecnologia de Massachusetts - MIT, nos Estados Unidos, lembra que um dos levantamentos sobre esse suposto conhecimento mínimo havia chegado a surpreendentes cinco mil conceitos, datas, nomes e expressões. A preocupação com alfabetização científica poderia ser ampliada: talvez seja injusto esperar o domínio de conceitos científicos básicos somente do leitor ou dos jornalistas, já que os próprios pesquisadores são especializados em uma área, mas podem ser leigos em outras. Vencido o vestibular, um engenheiro normalmente prefere esquecer quais são os componentes da célula, assim como um biólogo finalmente assume a ojeriza por geometria analítica.

Outro desafio é acertar o passo. Em seu artigo, o pesquisador alemão Hans Peter Peters mostra por que os jornalistas, quase sempre em busca de certezas e da síntese, nem sempre conseguem acompanhar os pesquisadores, habituais perseguidores da dúvida e da análise, em busca de um mesmo objetivo: noticiar um achado científico da forma mais clara e honesta possível, sem exageros nem imprecisões. Peters escreve: "Os cientistas, como pesquisadores, fazem parte de comunidades cientificas que não encorajam a comunicação para além dos limites da ciência e, em alguns casos, até mesmo desaprovam colegas que fazem isso. Isso ocorre não tanto pelo fato de os cientistas se envolverem na comunicação pública que é controversa, mas, sim, na forma como essa comunicação é feita: em muitos casos, ela não está de acordo com as normas das publicações cientificas, tais como, por exemplo, ter um estilo impessoal, um alto nível de precisão ou ser revisada pelos pares antes da publicação". De fato, um jornal diário não funciona como uma revista de zoologia especializada em artrópodes extintos, mas as peculiaridades e necessidades recíprocas não justificam os conflitos, que a princípio poderiam ser resolvidos por meio de estratégias de cooperação, já que eles próprios, os leitores e o próprio trabalho no laboratório saem ganhando na medida em que circulem mais notícias sobre ciência.

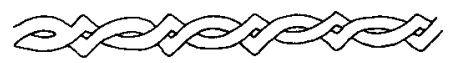




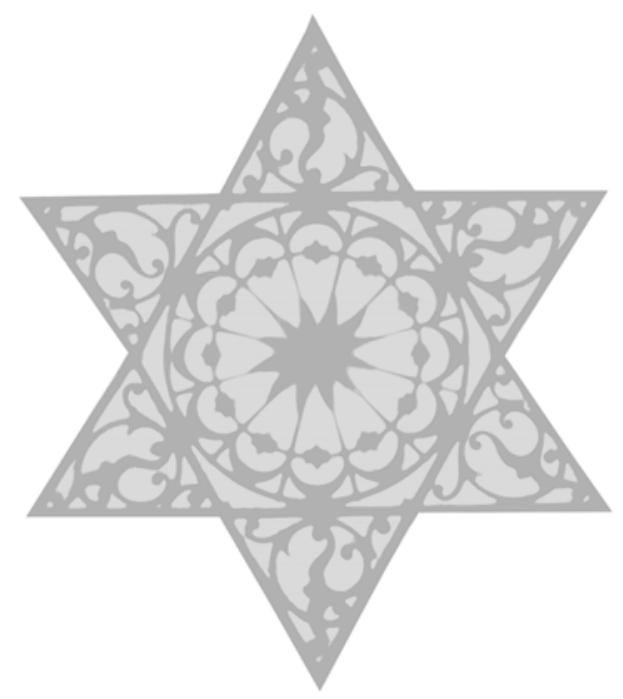

